GRZEGORZ BUJAK* - LUBLIN

\title{
ORGANIZACJA DEKANALNA DIECEZJI KIELECKIEJ W LATACH 1911-1925.
}

Początki sieci dekanalnej na terenie diecezji kieleckiej sięgają głęboko w przeszłość. Na przestrzeni dziejów odgrywała ona ważną rolę w zarządzaniu tutejszymi instytucjami kościelnymi ${ }^{1}$. W XX w. dekanaty wciąż stanowiły istotne ogniwo terenowej administracji kościelnej wymagane przez prawo kanoniczne ${ }^{2}$.

Do 1918 roku formalnie było w diecezji kieleckiej osiem dekanatów: kielecki, stopnicki, pińczowski, miechowski, olkuski, będziński, włoszczowski, jędrzejowski. Ich liczba ustaliła się w wyniku realizacji ukazu carskiego z 26 grudnia 1865 roku o dostosowaniu granic administracji kościelnej do podziałów państwowych. W stosunku do dekanatów w rozporządzeniu postanowiono, że będą obejmowały teren jednego powiatu, a dziekani mieli rezydować w miastach powiatowych. Uległo wówczas likwidacji 13 z 19 istniejących wcześniej na tym terenie dekanatów, a powstało dwa nowe włoszczowski i będziński. Zniesiono też urząd wicedziekana ${ }^{3}$.

Znaczne rozmiary dekanatów, od początku stanowiły poważne utrudnienie w ich prawidłowym funkcjonowaniu. Pod koniec 1917 roku najmniejszy pod względem liczby parafii był dekanat kielecki, który obejmował 9 parafii. Był to jednak wyjątek. Następny w kolejności był dekanat włoszczowski, który liczył aż 27 parafii. Największy zaś będziński 42 parafie.

* Grzegorz Bujak - dr historii, adiunkt w Katedrze Historii Ustroju i Administracji Polski, Instytut Historii, Wydział Nauk Humanistycznych KUL.

${ }^{1}$ B. Kumor, Poczatki organizacji dekanalnej na ziemiach polskich, , Roczniki Teologiczno-Kanoniczne”, 7 (1960) z. 2, s. 93-94; E. Wiśniowski, Rozwój sieci parafialnej w prepozyturze wiślickiej w średniowieczu. Studium geograficzno-historyczne, Warszawa 1965, s. 27-31; S. Litak, Kościót Łaciński w Rzeczypospolitej około 1772 roku. Struktury administracyjne, Lublin 1996, s. 52-55.

${ }^{2}$ F. Bączkowicz, Prawo kanoniczne. Podręcznik dla duchowieństwa, t. 1, Opole 1957, s. 571.

${ }^{3}$ Kumor, Poczatki organizacji dekanalnej, s. 221. 
Tabela nr 3. Liczba parafii w poszczególnych dekanatach w diecezji kieleckiej w latach 1917-1925

\begin{tabular}{|c|c|c|c|c|c|c|c|c|c|c|}
\hline \multirow{2}{*}{ Lp } & \multirow{2}{*}{ Dekanat } & \multicolumn{9}{|c|}{ Rok } \\
\hline & & 1917 & 1918 & 1919 & 1920 & 1921 & 1922 & 1923 & 1924 & 1925 \\
\hline 1 & kielecki & 9 & 12 & 12 & 13 & 13 & 13 & 13 & 13 & 13 \\
\hline 2 & stopnicki & 31 & 10 & 10 & 9 & 9 & 9 & 10 & 10 & 10 \\
\hline 3 & chmielnicki & & 11 & 11 & 12 & 12 & 12 & 12 & 12 & 12 \\
\hline 4 & pacanowski & & 10 & 10 & 11 & 11 & 11 & 11 & 11 & 11 \\
\hline 5 & pińczowski & 39 & 11 & 11 & 11 & 11 & 11 & 11 & 11 & 11 \\
\hline 6 & skalbmierski & & 10 & 10 & 10 & 10 & 10 & 10 & 10 & 10 \\
\hline 7 & kazimierski & & 9 & 9 & 9 & 9 & 9 & 9 & 9 & 9 \\
\hline 8 & książnicki & & 9 & 9 & 9 & 9 & 9 & 9 & 9 & 9 \\
\hline 9 & miechowski & 41 & 11 & 11 & 11 & 11 & 10 & 10 & 10 & 10 \\
\hline 10 & proszowicki & & 9 & 8 & 8 & 8 & 8 & 8 & 8 & 8 \\
\hline 11 & prandociński & & 12 & 12 & 12 & 12 & 12 & 12 & 12 & 12 \\
\hline 12 & luborzycki & & 10 & 10 & 10 & 10 & 10 & 10 & 10 & 10 \\
\hline 13 & olkuski & 32 & 10 & 11 & 11 & 12 & 12 & 13 & 13 & 13 \\
\hline 14 & zadroski & & 12 & 12 & 12 & 12 & 12 & 12 & 12 & 12 \\
\hline 15 & pilicki & & 10 & 10 & 10 & 10 & 10 & 10 & 10 & 10 \\
\hline 16 & będziński & 42 & 12 & 14 & 14 & 14 & 14 & 14 & 15 & 15 \\
\hline 17 & sączowski & & 11 & 7 & 7 & 7 & 7 & 7 & 7 & 7 \\
\hline 18 & zawierciański & & 8 & 13 & 15 & 15 & 15 & 15 & 15 & 15 \\
\hline 19 & żarecki & & 11 & 8 & 8 & 8 & 8 & 8 & 8 & 8 \\
\hline 20 & włoszczowski & 27 & 9 & 9 & 9 & 9 & 9 & 8 & 8 & 8 \\
\hline 21 & irządzki & & 9 & 9 & 9 & 9 & 9 & 9 & 9 & 9 \\
\hline 22 & szczekociński & & 9 & 9 & 9 & 9 & 9 & 10 & 10 & 10 \\
\hline 23 & jędrzejowski & 29 & 12 & 12 & 12 & 12 & 12 & 12 & 12 & 12 \\
\hline 24 & mokrski & & 8 & 8 & $*$ & & & & & \\
\hline 25 & krzcięcicki & & 9 & $*$ & & & & & & \\
\hline 26 & sędziszowski & & & 9 & 9 & 9 & 10 & 10 & 10 & 10 \\
\hline 27 & małogoski & & & & 8 & 8 & 8 & 8 & 8 & 8 \\
\hline \multicolumn{2}{|c|}{ RAZEM } & 250 & 254 & 254 & 258 & 259 & 259 & 261 & 262 & 262 \\
\hline
\end{tabular}

* rok likwidacji dekanatu

W celu usprawnienia struktury dekanalnej nowy biskup ordynariusz A. Łosiński w 1911 roku ustanowił 15 wicedziekanów. W tej sprawie zwrócił się do generał-gubernatora warszawskiego pismem z 4 kwietnia 1911 roku. Przedstawił w nim trudności płynące $\mathrm{z}$ faktu istnienia zaledwie ośmiu dekanatów w diecezji liczącej ponad milion wiernych i 245 parafii. W celu rozwiązania problemu proponował powołanie pomocników dziekanów zwanych wicedziekanami. Tylko w dekanacie kieleckim nie przewidywał utworzenia takiej funkcji. Dla dekanatów włoszczowskiego, jędrzejowskiego i olkuskiego proponował po dwóch wicedzie- 
kanów, a dla pozostałych po trzech. Biskup przedstawił również propozycję personalnej obsady tych urzędów ${ }^{4}$.

Generał-gubernator, pismem z 29 czerwca 1911 roku, przychylił się do prośby biskupa, zastrzegając jednak by nie naruszano praw i obowiązków dziekanów wypływających z przepisów państwowych. O każdej zmianie personalnej na stanowisku wicedziekana, biskup był zobowiązany powiadamiać właściwego gubernatora ${ }^{5}$. Wkrótce też nazwiska wicedziekanów zostały opublikowane w „Przeglądzie Diecezjalnym”. Byli to ci sami księża, których biskup przedstawił w piśmie do generał-gubernatora. Kompetencje wicedziekanów na forum wewnątrzkościelnym ordynariusz zrównał z prawami dawnych ośmiu dziekanów rezydujących w miastach powiatowych stwierdzając, że są oni „właściwymi dziekanami”. Jedynie w zakresie obowiązków wypływających z prawa państwowego dotychczasowi dziekani zachowywali swoje kompetencje. Dotyczyło to między innymi kontroli ksiąg metrykalnych ${ }^{6}$.

W nominacji wicedziekanów opublikowanej w „Przeglądzie Diecezjalnym” nazwano ich pomocnikami dziekanów w ramach istniejących dotąd struktur dekanatów powiatowych. Mimo braku oryginalnych dokumentów nominacyjnych dla poszczególnych wicedziekanów, istnieją podstawy aby sądzić, że przysługująca im jurysdykcja nie dotyczyła obszaru całego dekanatu, lecz ściśle określonej jego części. W aktach konsystorskich zachował się projekt nominacji na wicedziekana dekanatu będzińskiego dla dystryktu żareckiego. Niestety nie jest on datowany, ani nie zawiera informacji dla kogo imiennie był wystawiony. Jako obszar władzy wicedziekana, wymienione w nim zostało osiem parafii: Olsztyn, Źrębice, Złoty Potok, Przybynów, Myszków, Niegowa, Włodowice, Skarżyce. Z faktu pominięcia w tym wykazie parafii Żarki, należy wnosić, że pismo miało być przeznaczone dla proboszcza tej parafii, będącej równocześnie siedzibą wicedekanatu. Ponieważ nie wymieniono w nominacji parafii Janów, która została utworzona w 1912 roku ${ }^{7}$, a która ze względu na swoje położenie przy granicy diecezji nie mogła należeć do innego dekanatu ani wicedekanatu, należy przyjąć, że projekt nominacji pochodził sprzed tej daty. Ponieważ ks. Wincenty Cheliński był proboszczem i równocześnie wicedziekanem w Żarkach od 1911 roku $^{8}$, można przyjąć, że niedatowany dokument był minuta jego nominacji z 1911 roku. Byłby to zatem dowód, że już w 1911 roku, a zatem od początku swojego istnienia, wicedziekani posiadali ściśle określone okręgi podlegające ich władzy, a powołanie wicedziekanów było wstępem do podziału rozległych dekanatów powiatowych.

Zachowane notatki konsystorskie o zmianach na stanowiskach wicedziakanów z lat 1913-1915 nie zawierają informacji o zmianie okręgów wicedekanalnych ${ }^{9}$.

${ }^{4}$ Archiwum Diecezjalne w Kielcach (dalej ADK), Akta Dziekańskie Ogólne, sygn. OD 4/1, k. 371

${ }^{5}$ ADK, Akta Dziekańskie Ogólne, sygn. OD 4/1, k. 373.

${ }^{6}$ Nominacje, „Przegląd Diecezjalny” (dalej PrzD), 1 (1911) s. 146-147.

${ }^{7}$ Elenchus venerabilis cleris saecularis ac regularis dioecesis Kielcensis (dalej ElenchDK), (1913) s. 126.

${ }^{8}$ Zmiany w duchowieństwie, PrzD, 1 (1911) s. 179.

${ }^{9}$ ADK, Akta Dziekańskie Ogólne, sygn. OD 4/1 k. 374-378. 
Może to być pośrednim dowodem, że okręgi utworzone w okresie poprzednim były dosyć stabilne i przy każdorazowej zmianie wicedziekana nie zachodziła potrzeba ponownego wymieniania podlegających mu parafii. Natomiast $\mathrm{w}$ niektórych nominacjach wicedziekanów i dziekanów w latach 1915-1918 zostały ponownie wymienione $\mathrm{z}$ nazwy podlegające im parafie ${ }^{10}$. Było to spowodowane zmianami sieci dekanalnej z tamtego okresu, pojawianiem się nowych wicedekanatów i zanikaniem starych.

Jeszcze w 1911 roku, już po ogłoszeniu w „Przeglądzie Diecezjalnym” listy wicedziekanów, zaszły dwie zmiany. Zamiast wicedziekana w Grodźcu został wicedziekanem proboszcz parafii Żarki (zapewne w związku z tą zmianą przygotowano omówiony wyżej projekt nominacji), a zamiast wicedziekana w Nowym Brzesku został wicedziekanem proboszcz w Książnicach Wielkich. Ostatecznie też te parafie utrwaliły się jako siedziby wicedziekanów ${ }^{11}$. W latach 1912-1918, doszło do kolejnych zmian siedzib wicedziekanów. W 1912 roku przeniesiony został wicedekanat z Chruszczobrodu do Sączowa ${ }^{12}$. Dnia 5 czerwca 1915 roku został mianowany wicedziekan w Krzcięcicach na miejsce zlikwidowanego wicedekanatu wodzisławskiego ${ }^{13}$. W 1913 roku przeniesione zostały wicedekanaty z Solca i Szańca do Biechowa i Piotrkowic ${ }^{14}$, a w 1918 roku do Pacanowa i Chmielnika ${ }^{15}$. Jeszcze przed 1917 roku przeniesione zostały siedziby wicedziekanów z Przeginii, Chliny i Konieczna do Zadroża, Pilicy i Szczekocin ${ }^{16}$. Zamiast w Rokitnie w 1913 roku powstał wicedekanat w Dzierzgowie ${ }^{17}$. Tylko w dwóch dekanatach powiatowych: miechowskim i pińczowskim, w latach 1911-1918 siedziby dziekanów i wicedziekanów pozostały w tych samych parafiach ${ }^{18}$. Dowodzi to trwałości podziału tych dekanatów na okręi wicedekanalne. Dodatkowo wzmacniał go fakt, że w dekanacie miechowskim funkcje wicedziekanów pełnili bez zmiany ci sami księża proboszczowie w Proszowicach, Luborzycy i Prandocinie.

W wyniku przemian struktury dekanalnej w diecezji kieleckiej w latach 19111918 utrwalił się podział na 25 jednostek administracyjnych tego rodzaju: 8 dekanatów i 17 wicedekanatów, w których wyznaczeni przez biskupa księża sprawowali faktyczną władzę dziekańską.

Nie zachował się dokument biskupa kieleckiego zamieniający wicedekanaty na dekanaty. Brak jest również informacji na ten temat w „Przeglądzie Diecezjalnym". Najprawdopodobniej było tak dlatego, że od początku istnienia wicedekanatów stanowiły one jednostki równe dekanatom wobec prawa kościelnego. Biskup A. Łosiński w piśmie do administratora diecezji lubelskiej z 1917 roku

\footnotetext{
${ }^{10}$ ADK, Akta Dziekańskie Ogólne, sygn. OD 4/1 k. 380-381, 392-396.

${ }^{11}$ Nominacje, PrzD, 1 (1911) s. 146-147.

${ }^{12}$ ElenchDK, (1913) s. 18.

${ }^{13}$ ADK, Akta Dziekańskie Ogólne, sygn. OD 4/1, k. 380.

${ }^{14}$ ElenchDK, (1914) s. 17.

${ }^{15}$ ElenchDK, (1919) s. 12-13.

${ }^{16}$ ElenchDK, (1918) s. 141-142.

${ }^{17}$ ElenchDK, (1914) s. 17.

${ }^{18}$ ElenchDK, za lata 1912-1919.
} 
stwierdził, że w jego planach od samego początku wicedekanaty były jednostkami samodzielnymi, a jedynie ze względu na prawodawstwo państwowe „utrzymywano fikcję zależności wicedziekanów od dziekanów powiatowych." ${ }^{19}$.

Można jednak dość dokładnie ustalić kiedy ta „fikcja” przestała być podtrzymywana. W elenchusie diecezjalnym na rok 1918, wydanym pod koniec roku 1917, umieszczono jeszcze tradycyjny podział na dekanaty i wicedziekanów. W projektach dekretów nominacyjnych z dnia 27 lutego 1918 roku dla dwóch proboszczów w Pacanowie i Chmielniku na wicedziekanów, przekreślono słowo „wicedziekan” zastępując je terminem „dziekan”20. Zatem formalne usamodzielnienie wicedekanatów należy umieścić w początkach 1918 roku. Łączyć to należy zapewne z ogólną sytuacją polityczną w kraju, dającą podstawy do podejmowania przez administrację kościelną bardziej zdecydowanych i samodzielnych posunięć. W elenchusie z 1919 roku, wydanym pod koniec roku poprzedniego, zostały po raz pierwszy ogłoszone drukiem nazwy 25 dekanatów wraz z wykazem należących do nich parafii.

Powstałe w wyniku omówionych procesów jednostki administracyjne nawiązywały do tradycji dawnych dekanatów na tym terenie. Siedziby dziekanów w wielu wypadkach umieszczono w parafiach, które historycznie były związane z tymi urzędami. Bywało jednak, że wskutek takiego prostego nawiązywania do przeszłości $\mathrm{w}$ zmienionych warunkach społecznych, nowe dekanaty nie zawsze były funkcjonalne. Zdarzało się, że parafie należące do jednego dekanatu nie posiadały odpowiedniej komunikacji z siedzibą własnego dziekana, lub było z nich bliżej do innego dziekana. Dlatego też w latach 1919-1921 przeprowadzono korekty granic dekanatów. Brak zachowanej dokumentacji z tego okresu nie pozwala na odtworzenie procesu podejmowania odpowiednich decyzji i kryteriów, jakimi posługiwano się przeprowadzając zmiany. Na uwagę zasługuje jednak fakt, że zmieniając granice, starano się, pomijając sytuacje już istniejące, nie łączyć w jednym dekanacie parafii z różnych powiatów. Można się w tym doszukiwać pewnego dążenia do zachowywania związku między strukturą administracji państwowej i kościelnej, nawiązującego do praktyki w tym zakresie właściwej dla okresu rozbiorów.

Na podstawie danych z elenchusów można ustalić, że w pierwszej kolejności w 1919 roku dokonano korekty granic dekanatów powstałych z trzech dawnych dekanatów powiatowych, leżących w południowej i zachodniej części diecezji: będzińskiego, olkuskiego i miechowskiego. Przynależność dekanalną zmieniło wówczas dziesięć parafii.

Z dekanatu prandocińskiego do olkuskiego odeszła parafia Poręba Górna, przyłączona natomiast do niego została parafia Pałecznica z dekanatu proszowickiego. Z dekanatu zadroskiego odeszła do dekanatu luborzyckiego parafia Nara$\mathrm{ma}^{21}$. Z dekanatu żareckiego do zawierciańskiego przeszły trzy parafie Skarżyce, Włodowice i Myszków. Dekanat zawierciański został równocześnie powiększony o dwie parafie z dekanatu sączowskiego: Chruszczobród i Niegowonice. Dwie

\footnotetext{
${ }^{19}$ ADK, Akta Dziekańskie Ogólne, sygn. OD 4/1, k. 401.

${ }^{20}$ ADK, Akta Dziekańskie Ogólne, sygn. OD 4/1, k. 408-409.

${ }^{21}$ ElenchDK, (1920) s. 55.
} 
inne parafie z dekanatu sączowskiego, Łęka i Ząbkowice, zostały przyłączone do dekanatu będzińskiego ${ }^{22}$.

Zmiany te wpłynęły na przybliżenie parafii do siedzib dziekanów. Dekanat żarecki uzyskał w wyniku przeprowadzonych korekt jednolity charakter rolniczy. Przed zmianą granic należało do niego siedem parafii $\mathrm{z}$ powiatu będzińskiego i cztery z częstochowskiego, wskutek czego posiadał on charakter przemysłowo-rolniczy. Odłączono od niego parafie, w których dynamicznie rozwijały się środowiska ludności związanej z przemysłem i przyłączono je do dekanatu będzińskiego, obejmującego najbardziej uprzemysłowione tereny diecezji.

W 1919 roku rozpoczęto także reformę sieci dekanalnej w powiecie jędrzejowskim, kontynuowaną w latach następnych. W 1918 roku powiat ten był podzielony na 3 dekanaty: jędrzejowski, mokrski i krzcięcicki. W 1919 roku doszło do przemianowania dekanatu krzcięcickiego na sędziszowski, jednak bez zmiany jego granic. Zmiana ta połączona była z odejściem z Krzcięcic ks. Jana Chwistka, który obowiązki proboszcza tej parafii i dziekana pełnił zaledwie przez dwa lata. Obejmując położone w tym samym dekanacie probostwo w Tarnawie, złożył on urząd dziekana ${ }^{23}$. W świetle zachowanego materiału źródłowego przyczyna tych zmian nie jest w pełni jasna. Protokół wizytacji biskupiej odbytej w maju 1918 roku nie wskazywał na ewentualne problemy, które mogły być przyczyną tej zmiany ${ }^{24}$. Być może odejście ks. J. Chwistka z parafii liczącej prawie 6 tysięcy wiernych, na mniejszą liczącą 1670 wiernych należy wiązać $z$ jego wiekiem (64 lata) lub stanem zdrowia. Z zachowanych akt parafii Krzcięcice wiadomo, że mimo znacznej liczby wiernych, miała ona trudności finansowe ${ }^{25}$.

Nowym dziekanem został ks. Antoni Zimniak, administrator parafii Sędziszów, a siedziba dziekana i nazwa dekanatu na stałe zostały związane z tą parafią ${ }^{26}$. Na korzyść Sędziszowa przemawiało wiele atutów. Była to druga co do wielkości parafia dekanatu, i w przeciwieństwie do mających rolniczy charakter Krzcięcic, ze znacznymi perspektywami na rozwój gospodarczy. Sędziszów był bowiem położony przy ważnej linii kolejowej i posiadał dogodną komunikację z powiatowym Jędrzejowem i siedzibą biskupa w Kielcach ${ }^{27}$.

W 1920 roku doszło do likwidacji dekanatu mokrskiego. Zmian dokonał biskup A. Łosiński dekretem z 10 maja, opublikowanym w Przegladzie Diecezjal$n y m^{28}$. Wchodząca w skład dekanatu mokrskiego parafia Łukowa, została przyłączona do dekanatu kieleckiego. Sześć dalszych: Mokrsko, Chomentów, Imielno, Korytnica, Mnichów i Sobków - do dekanatu jędrzejowskiego. Równocześnie sześć parafii z dekanatu jędrzejowskiego: Małogoszcz, Kozłów, Oksa, Rem-

${ }^{22}$ ElenchDK, (1920) s. 66, 69.

${ }^{23}$ ADK, Akta Personalne Księdza Jana Chwistka, sygn. XC - 7, k. 29, 34; ElenchDK, (1920) s. 89.

${ }^{24}$ ADK, Wykazy wizytacji w parafiach,sygn. OD 1/10, k. 109-110.

${ }^{25}$ ADK, Akta Parafii Krzcięcice, sygn. PK 33/1, k. 195-200.

${ }^{26}$ ElenchDK, (1920) s. 66.

${ }^{27}$ S. Borkiewicz, Z. Linowski, Monografia historyczna i gospodarcza powiatu jędrzejowskiego, Kielce 1937, s. 298-299.

${ }^{28}$ Z kieleckiej Kurii Biskupiej, PrzD, 7 (1920) s. 85. 
bieszyce, Węgleszyn, Złotniki weszło w skład nowego dekanatu małogoskiego, do którego ponadto przyłączono parafie Bolmin z dekanatu kieleckiego i Brzegi z likwidowanego mokrskiego.

Brak dokumentacji nie pozwala na ustalenie przyczyn tak radykalnych zmian sieci dekanalnej na tym terenie. Trzeba jednak zauważyć, że w parafii Mokrsko we wcześniejszym okresie, dochodziło często do zmiany proboszczów, którzy szybko rezygnowali z kierowania nią, najprawdopodobniej ze względu na niewielkie dochody. W okresie wakansu jej zarząd był powierzany tymczasowo proboszczowi w Mnichowie ${ }^{29}$. Ten brak stabilności na stanowisku proboszcza wpływał negatywnie na sprawowanie urzędu dziekana związanego z parafią w Mokrsku i zapewne był jedną z ważnych przyczyn reorganizacji sieci dekanalnej.

Należy zwrócić uwagę na fakt, że był to drugi po Krzcięcicach wypadek likwidacji na tym terenie siedziby dziekana $\mathrm{w}$ parafii, z którą urząd ten był tradycyjnie związany. Zmiany te należy zapewne tłumaczyć spadkiem znaczenia obu parafii, między innymi z powodów gospodarczo-finansowych. Było to zapewne przejawem głębszych przemian społeczno-gospodarczych na obszarze powiatu jędrzejowskiego, które powodowały upadek znaczenia dawnych centrów administracyjno-społecznych i wzrost znaczenia innych, dysponujących na tyle silnymi atutami, by przejąć zadania starych ośrodków. W wypadku Sędziszowa i Małogoszcza było to między innymi położenie w pobliżu linii kolejowej.

Podczas likwidacji dekanatu mokrskiego po raz pierwszy wyraźnie nie brano pod uwage przynależności parafii do struktur powiatowych. W dekanacie kieleckim znalazła się parafia Łukowa z powiatu jędrzejowskiego, a w dekanacie małogoskim parafia Bolmin z kieleckiego. Jak się wydaje w tym czasie władze diecezjalne uznały za zbędne uwzględnianie podziałów administracyjnych państwowych przy kreowaniu sieci dekanalnej w diecezji, wychodząc z założenia, że ograniczenia prawa zaborczego $\mathrm{w}$ tym względzie przestały obowiązywać. Tam jednak, gdzie nie kolidowało to z celami duszpasterskimi, zachowywano jedność administracji kościelnej i państwowej dekanatu. Tak było w przypadku przesunięcia w tym samym 1920 roku parafii Szaniec z dekanatu stopnickiego do chmielnickiego ${ }^{30}$. Samodzielności władz kościelnych w kwestiach reform administracyjnych sprzyjała przeprowadzana w tym samym czasie reforma struktur administracji państwowej ${ }^{31}$.

Przed podziałem diecezji w 1925 roku miały miejsce jeszcze dwa wypadki przesunięcia parafii do innego dekanatu. Dekretem biskupa z 21 lutego 1922 roku, przeniesiona została parafia Kozłów z dekanatu miechowskiego do sędziszowskiego $^{32}$. Miała ona dogodną komunikację kolejową zarówno z Miechowem jak i z Sędziszowem. Była jednak położona bliżej Sędziszowa, z którym dodatkowo łączyła ją dobra szosa ${ }^{33}$. Natomiast w 1923 roku z dekanatu włoszczowskiego do

\footnotetext{
${ }^{29}$ ADK, Akta Parafii Mokrsko, sygn. PM 13/1, k. 448, 449, 456.

${ }^{30}$ ElenchDK, (1921) s. 30.

${ }^{31}$ A. Ajnenkiel, Administracja w Polsce. Zarys historyczny, Warszawa 1975, s. 54-55.

${ }^{32}$ ADK, Akta Dziekańskie Ogólne, sygn. OD 4/2, k. 17.

${ }^{33}$ Borkiewicz, Linowski, Monografia historyczna, s. 302-303.
} 
szczekocińskiego przeniesiono parafię Secemin ${ }^{34}$. Zachowana dokumentacja nie pozwala na odtworzenie okoliczności, które doprowadziły do tej zmiany. Tym bardziej jest to zastanawiające, gdyż parafia ta była od reszty dekanatu szczekocińskiego oddzielona rzeką Nidą i bagnami. W 1936 roku powróciła ona w skład dekanatu włoszczowskiego ${ }^{35}$.

Omówione powyżej zmiany granic w latach 1919-1923 objęły 18 z 25 dekanatów co stanowiło $72 \%$ ich ogółu. Nie zmienione zostały granice siedmiu dekanatów: irządzkiego, miechowskiego, pacanowskiego, pińczowskiego, książnickiego, kazimierskiego i skalbmierskiego. Ostatnie cztery wymienione dekanaty należały wcześniej do dekanatu powiatowego z siedzibą w Pińczowie.

Przynależność dekanalną zmieniło 26 parafii co stanowiło ok. 10\% ogółu. Pod względem powierzchni najbardziej rozległy były dekanaty jędrzejowski i chmielnicki. Pod względem liczby parafii w poszczególnych dekanatach panowało znaczne zróżnicowanie. Po zmianach granic w 1919 roku najmniej, bo zaledwie 7 parafii, liczył dekanat sączowski. Najwięcej, bo aż po 15 parafii należało do dekanatów będzińskiego i zawierciańskiego. Spowodowane to było wzrostem liczby parafii nowo tworzonych w tych dekanatach. Ogólna tendencja przy reorganizacji okręgów dekanalnych była przeciwna, gdyż dążono do zmniejszenia liczby parafii w dekanacie. Utworzony w 1920 roku dekanat małogoski liczył osiem parafii i zachował tę liczbę do połowy lat trzydziestych. W przededniu podziału diecezji w 1925 roku osiem dekanatów liczyło poniżej 10 parafii, dwa dekanaty po 11, cztery po 12 , dwa po $13 \mathrm{i}$ dwa po 15 . Najliczniejszą grupę bo aż siedem stanowiły dekanaty liczące po 10 parafii. Dużą stabilnością okręgów charakteryzowały się te dekanaty, których dziekani rezydowali w miasteczkach powiatowych. Posiadały one równocześnie największe okręgi dekanalne. Aż siedem z nich posiadało dziesięć i więcej parafii. Wyjątkiem były dekanat włoszczowski liczacy 9, a od 1923 roku 8 parafii. Trzeba też podkreślić wyjątkową stabilność sieci dekanalnej w powiecie pińczowskim. Był to jedyny w diecezji przypadek, kiedy granice i siedziby funkcjonujących tam dekanatów, a wcześniej wicedekanatów: pińczowskiego, kazimierskiego, skalbmierskiego i książnickiego, nie uległy żadnym zmianom w latach 1911-1925.

W procesie reorganizacji struktur dekanalnych w latach 1918-1925 można zauważyć tendencję nie tylko do zmniejszania liczby parafii należących do dekanatów, ale także wyrównywania ich pod względem liczby wiernych. Ostrożnie należy traktować statystyki ludności zamieszczane w elenchusach. Zdarzało się bowiem, że księża w przesyłanych do kurii wykazach przez wiele kolejnych lat podawali taką samą liczbę wiernych. Dlatego dane te i dokonywane na ich podstawie obliczenia zawarte w poniższej tabeli należy traktować jako przybliżone.

\footnotetext{
${ }^{34}$ ElenchDK, (1924) s. 69.

${ }^{35}$ ElenchDK, (1937) s. 145.
} 
Tabela nr 2. Liczba ludności w poszczególnych dekanatach w latach 1918 i 1924

\begin{tabular}{|l|c|c|}
\hline \multirow{2}{*}{ dekanat } & \multicolumn{2}{|c|}{ rok } \\
\cline { 2 - 3 } & 1918 & 1924 \\
\hline kielecki & 84.697 & 88.517 \\
\hline stopnicki & 46.568 & 45.455 \\
\hline chmielnicki & 45.884 & 52.248 \\
\hline pacanowski & 35.737 & 37.109 \\
\hline pińczowski & 32.432 & 31.725 \\
\hline skalbmierski & 30.887 & 32.439 \\
\hline kazimierski & 26.985 & 26.985 \\
\hline książnicki & 18.354 & 18.354 \\
\hline miechowski & 45.689 & 45.218 \\
\hline proszowicki & 27.172 & 24.095 \\
\hline prandociński & 23.133 & 25.120 \\
\hline luborzycki & 31.297 & 33.979 \\
\hline olkuski & 50.667 & 52.317 \\
\hline zadroski & 44.561 & 40.833 \\
\hline pilicki & 35.237 & 36.161 \\
\hline będziński & 173.043 & 192.143 \\
\hline sączowski & 41.147 & 32.280 \\
\hline zawierciański & 55.860 & 75.503 \\
\hline żarecki & 34.407 & 25.759 \\
\hline włoszczowski & 32.186 & 32.187 \\
\hline irządzki & 27.665 & 28.955 \\
\hline szczekociński & 22.609 & 24.709 \\
\hline jędrzejowski & 38.056 & 37.529 \\
\hline mokrski & 20.283 & brak dek. \\
\hline krzcięcicki & 33.505 & brak dek. \\
\hline małogoski & 19.952 \\
\hline sędziszowski & brak dek. & 1.095 .833 \\
\hline RAZEM & brak dek. & \\
\hline & 1.058 .063 & \\
\hline & & \\
\hline & & \\
\hline
\end{tabular}

Jak z nich wynika w 1918 roku w dziewięciu dekanatach mieszkało po trzydzieści kilka tysięcy wiernych. W siedmiu od czterdziestu do pięćdziesięciu kilku tysięcy, i w takiej samej liczbie poniżej trzydziestu tysięcy wiernych. Najwięcej katolików skupiały dekanaty będziński i kielecki, znajdujące się w najbardziej uprzemysłowionych rejonach diecezji. Pod tym względem odbiegały one wyraźnie od reszty dekanatów diecezji. Różnica między liczącym najmniej wiernych dekanatem książnickim, a dekanatem będzińskim była aż dziewięciokrotna. W wyniku zmian w sieci dekanalnej dokonanych jeszcze przed reorganizacją granic diecezji w 1925 roku, proporcje te nie zostały zachwiane. Najliczniejszą grupę dekanatów stanowiły wciąż te, które skupiały po około 30 tysięcy wiernych. Największą dynamikę przyrostu wiernych wykazywały dekanaty będziński i zawierciański. Przyczyn tych zmian należy się jednak doszukiwać w większym stopniu $\mathrm{w}$ przeprowadzonych zmianach granic dekanatów, aniżeli w gwałtownych ruchach migracyjnych. 
Do 1925 roku najbardziej stabilna była sieć dekanalna na terenach południowych diecezji kieleckiej. Okręgi dekanalne były tam niewielkie terytorialnie. Wypływało to $\mathrm{z}$ faktu znacznego nasycenia tych terenów siecią parafialną. Wydaje się też, że struktura ludnościowa tych terenów o stosunkowo wysokiej kulturze rolnej sprzyjała utrwalaniu struktur administracji kościelnej, które w istniejącym wówczas kształcie, odpowiadały lokalnym potrzebom. W gospodarczo ubogich, centralnie położonych dekanatach diecezji (w regionie jędrzejowskim), nasycenie siecią parafialną było mniejsze niż na południu. Stagnacja gospodarcza pewnych tamtejszych rejonów, z reguły o starszej tradycji, połączona z równoczesnym rozwojem nowych centrów gospodarczych i społecznych, jak Sędziszów, wymagała większej reorganizacji struktur administracji kościelnej, by dostosować ich kształt do nowych potrzeb.

Największą jednak dynamikę zmian struktury dekanalnej wykazywał rejon Zagkębia Dąbrowskiego. Rekonstrukcje dokonane w latach 1918-1923 doprowadziły tylko częściowo do rozwiązania problemów infrastruktury religijnej tamtego terenu, zamieszkiwanego przez zróżnicowaną pod wieloma względami i dynamicznie rozwijającą się społeczność. Duże okręgi dekanalne, rosnące wskutek erekcji nowych parafii, musiały ulegać częstszym i głębszym reorganizacjom.

\title{
DIE DEKANATSORGANISATION DER DIÖZESE KIELCE IN DEN JAHREN 1911-1925
}

\author{
Zusammenfassung
}

Nach einer Zeit der Stagnation, ja Regression in der Entwicklung des Dekanatsnetzes auf dem Territorium der Diözese Kielce im 19. Jahrhundert erfolgte in den Jahren 1911-1925 dessen dynamische Entfaltung. Dies geschah in mehreren Etappen. Die erste betraf die Berufung von Vizedechanten im Rahmen ausgedehnter Kreisdekanate im Jahre 1911, darauf folgte 1918 die Umgestaltung der Vizedekanatsbezirke zu selbständigen Dekanaten, und der dritte Schritt bestand in der Reform der Dekanatsgrenzen in den Jahren 1919-1921. Im Ergebnis dieser Umgestaltungen wurde das Dekanatsnetz in der Diözese Kielce weitgehend der neuen sozialen und demographischen Situation angepasst und überdauerte so bis zur Reorganisation der Diözesengrenzen im Jahre 1925 . 